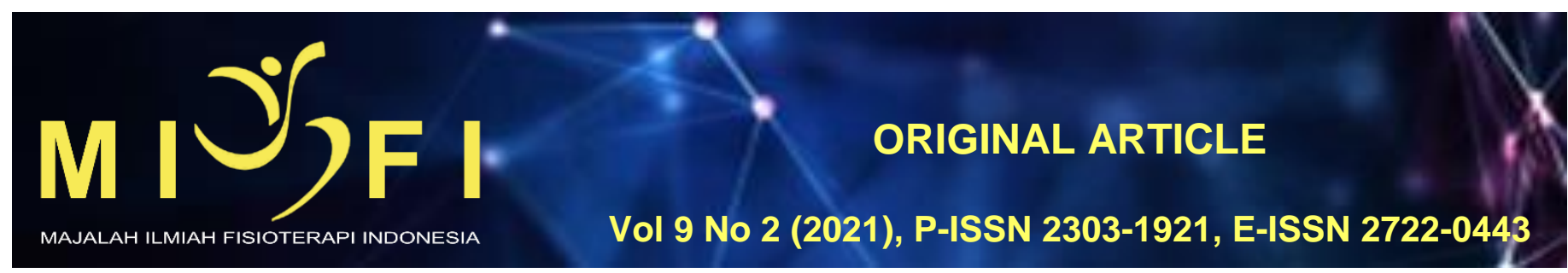

\title{
PERBEDAAN TINGKAT KECEMASAN PADA IBU HAMIL TRIMESTER KETIGA YANG MENGIKUTI DENGAN YANG TIDAK MENGIKUTI PRENATAL YOGA DI KABUPATEN GIANYAR
}

\author{
Ni Luh Dian Apsari', Ni Komang Ayu Juni Antari², Indira Vidiari Juhanna ${ }^{3}$, I Putu Gede Adiatmika ${ }^{4}$ \\ ${ }^{1}$ Program Studi Sarjana Fisioterapi dan Profesi Fisioterapi, Fakultas Kedokteran, Universitas Udayana, Denpasar, Bali \\ ${ }^{2}$ Departemen Fisioterapi, Fakultas Kedokteran, Universitas Udayana, Denpasar, Bali \\ ${ }^{3,4}$ Departemen IImu Faal, Fakultas Kedokteran, Universitas Udayana, Denpasar, Bali \\ dianapsari836@yahoo.co.id
}

\begin{abstract}
ABSTRAK
Selama periode kehamilan ibu hamil mengalami perubahan fisiologis dan psikologis yang menyebabkan ibu hamil menjadi tidak nyaman, sehingga emosi yang dimiliki cenderung berubah-ubah. Seiring bertambahnya usia kehamilan, ibu hamil umumnya mulai merasakan kecemasan terutama pada trimester ketiga. Kecemasan berlebih akan memicu terjadinya stres dan berdampak pada kesehatan ibu dan janin. Salah satu terapi yang dapat dilakukan adalah prenatal yoga. Prenatal yoga adalah kegiatan olah tubuh, pikiran dan mental yang membantu ibu hamil melenturkan persendian dan menenangkan pikiran. Penelitian ini bertujuan untuk mengetahui apakah ada perbedaan tingkat kecemasan pada ibu hamil trimester ketiga yang mengikuti prenatal yoga dengan ibu hamil trimester ketiga yang tidak mengikuti prenatal yoga. Penelitian ini merupakan penelitian observasi analitik komperatif, dengan pendekatan cross sectional. Teknik pengambilan sampel purposive sampling dengan jumlah sampel 80 ibu hamil. Pengumpulan data dilakukan dengan mengukur tingkat kecemasan menggunakan kuesioner DASS 42. Tingkat kecemasan pada kelompok prenatal yoga terdapat $31 \mathrm{ibu}$ hamil tidak mengalami kecemasan $(77,5 \%)$ dan 9 ibu hamil mengalami kecemasan ringan $(22,5 \%)$, pada kelompok ibu hamil yang tidak mengikuti prenatal yoga terdapat 20 ibu hamil tidak mengalami kecemasan (50\%), 17 ibu hamil mengalami kecemasan ringan (42,5\%), 3 ibu hamil mengalami kecemasan sedang (7,5\%), dan tidak ada yang mengalami kecemasan berat maupun sangat berat $(0 \%)$. Perhitungan analisis data menggunakan uji Chi Square Test, diperoleh $p$ sebesar 0.020 sehingga $p<0.05$. Simpulan dari penelitian ini adalah terdapat perbedaan tingkat kecemasan pada ibu hamil trimester ketiga yang mengikuti prenatal yoga dengan ibu hamil trimester ketiga yang tidak mengikuti prenatal yoga di Kabupaten Gianyar.
\end{abstract}

Kata kunci: Prenatal Yoga, Kehamilan, Kecemasan

\section{THE DIFFERENCE OF ANXIETY LEVELS IN THIRD TRIMESTER PREGNANT WOMEN WHO ATTEND WITH THIRD TRIMESTER PREGNANT WOMEN WHO DOES NOT ATTEND PRENATAL YOGA WOMEN IN GIANYAR REGENCY}

During the pregnancy period, pregnant women experience physiological and psychological changes that cause pregnant women to be uncomfortable, so that their emotions tend to change. As increasing age of the pregnancy, pregnant women generally begin to feel anxiety, especially in the third trimester. Excessive anxiety will trigger stress and have an impact on the health of the women and fetus. One of the therapies that can be done is prenatal yoga. Prenatal yoga is a body, mind and mental exercise that helps pregnant women flex their joints and calm the mind. This study aims to determine whether there are differences in anxiety levels in third trimester pregnant women who attend prenatal yoga with third trimester pregnant women who do not attend prenatal yoga. This research is a comparative analytic observational study, with cross sectionalmethod. The sampling technique is purposive sampling with a sample of 80 pregnant women. Data collection was done by measuring the level of anxiety using the DASS 42 questionnaire. Anxiety levels in the prenatal yoga group were 31 pregnant women without anxiety (77.5\%) and 9 pregnant women experiencing mild anxiety $(22.5 \%)$, in the group of pregnant women who did not participate in prenatal yoga there were 20 pregnant women without anxiety (50\%), 17 pregnant women experienced mild anxiety $(42.5 \%), 3$ pregnant women experienced moderate anxiety $(7.5 \%)$, and none experienced severe or very severe anxiety ( $0 \%)$. Calculation of data analysis using the Chi Square Test, obtained $p$ of 0.020 so that $p<0.05$. The conclusion from this study is that there are differences in the anxiety levels in third trimester pregnant women who attend prenatal yoga with third trimester pregnant women who does not attend prenatal yoga in Gianyar Regency.

Keywords: Prenatal Yoga, Pregnancy, Anxiety

\section{PENDAHULUAN}

Wanita dewasa seiring bertambahnya usia, pada umumnya mereka akan memikirkan pernikahan dan memiliki keturunan. Setiap wanita tentu menginginkan keturunan yang sehat baik fisik maupun mental, sehingga ibu sangat memperhatikan asupan gizi bayi yang dikandungnya, namun psikologis ibu sering kali diabaikan. Psikologis ibu hamil pada kenyataanya memberikan dampak pada ibu dan janin yang dikandungnya, sehingga psikologis ibu hamil juga penting untuk diperhatikan. 
Kehamilan merupakan proses alamiah yang dialami wanita untuk menghasilkan keturunan. Seiring bertambahnya usia kehamilan, terjadi perubahan fisiologis dan psikologis pada ibu hamil. Perubahan fisiologis yang terjadi seperti mual, muntah, rasa tidak nyaman pada payudara, perut membesar, serta berhentinya menstruasi. Perubahan tersebut dapat menyebabkan ibu hamil menjadi tidak nyaman, sehingga emosi yang dimiliki cenderung berubah-ubah seperti mudah tersinggung, marah, sedih atau justru sangat bahagia tanpa sebab yang jelas, sesuai dengan tahapan kehamilan yang dilalui. ${ }^{1}$ Kehamilan dibagi menjadi tiga trimester, trimester pertama usia 0-3 bulan kehamilan, trimester kedua 4-6 bulan, dan trimester ketiga 7-9 bulan. ${ }^{2}$ Perubahan fisiologis dan psikologis pada trimester ketiga akan menimbulkan kecemasan lebih tinggi dibandingkan dua trimester sebelumnya, seperti halnya khawatir mengenai keselamatan bayi dan ibu, takut akan rasa sakit persalinan dan khawatir bayi dilahirkan dalam keadaan tidak normal. Kecemasan yang berlebih akan memicu terjadinya stres dan memberika dampak buruk bagi ibu dan janin. ${ }^{3}$

Kecemasan merupakan suatu perasaan khawatir yang berlebihan dan objeknya tidak jelas, menimbulkan gejala emosional, kognitif, tingkah laku dan fisik. ${ }^{4}$ Kecemasan pada ibu hamil terdiri dari dua faktor yaitu, faktor internal dan eksternal. Faktor eksternal yang mempengaruhi seperti dukungan suami dan keluarga serta ekonomi. ${ }^{5,6,7}$ Faktor internal berasal dari dalam diri sendiri meliputi usia, pendidikan, paritas. ${ }^{1}$

Gejala kecemasan ibu hamil yang dilaporkan dari 34 negara-negara dalam review article Dennis et al pada tahun 2017, pada trimester pertama sebesar 18,2\%, trimester kedua 19,1\%, dan trimester ketiga $24,6 \% .^{8}$ Proporsi wanita hamil di Indonesia menurut Riskesdas 2013 adalah 2,68\%. Tahun 2008 di Indonesia terdapat 373.000 .000 ibu hamil, dan yang mengalami kecemasan dalam mengahadapi proses persalinan ada sebanyak 107.000 .000 ibu hamil (28\%). ${ }^{5}$ Penelitian Rosyidah pada tahun 2015 di salah satu klinik bersalin di Mojokerto, dari 20 ibu hamil, ditemukan kecemasan sedang dialami oleh 13 orang (65\%), dan tidak ditemukan ibu hamil yang mengalami kecemasan sangat berat. $^{9}$

Pengendalian kecemasan melaui ketenangan dan relaksasi tubuh bisa didapatkan melalui terapi musik, intervensi kognitif-perilaku, aromaterapi, yoga, teknik relaksasi, ${ }^{10}$ hynobrithing. ${ }^{11}$ Yoga merupakan jenis latihan relaksasi pikiran-tubuh-roh yang gerakannnya dimodifikasi agar sesuai dengan kompetensi wanita hamil. ${ }^{10}$ Yoga terdiri dari serangkaian gerakan yang menggabungkan latihan peregangan dengan pernapasan dalam yang mampu meningkatkan aliran oksigen ke otak, relaksasi dan meditasi. ${ }^{12}$ Menurut Negari \& Christiani pada tahun 2015 yoga merupakan kegiatan olah tubuh, pikiran dan mental yang sangat membantu ibu hamil melenturkan persendian dan menenangkan pikiran terutama dalam trimester ketiga. Prenatal yoga memberikan beberapa manfaat seperti kesiapan fisik dan psikologis ibu hamil dalam menghadapi persalinan, mempersiapkan persalinan normal tanpa komplikasi, mempercepat persalinan kala dua, serta mengurangi kecemasan. ${ }^{13}$ Pratignyo tahun 2014 menyebutkan bahwa prenatal yoga berfungsi meningkatkan kesadaran dan kepercayaan diri pada ibu hamil dan menciptakan ikatan batin antara ibu dan bayi yang dikandung. ${ }^{14}$

Gerakan yoga memberikan efek pada perubahan aktivitas sistem saraf otonom. Saraf otonom menurut fungsinya dibagi menjadi dua yaitu saraf simpatis dan parasimpatis, yang dimana saraf tersebut memiliki sitem kerja yang berlawanan dalam mengendalikan kinerja suatu organ tubuh. ${ }^{15}$ Kegiatan yoga akan menyebabkan aktivitas saraf simpatis mengalami penurunan dan aktivitas saraf parasimpatis akan meningkat dan berpengaruh pada perlambatan kerja alat-alat internal dalam tubuh, sehingga irama nafas, ketegangan otot, tekanan darah, detak jantung, tingkat metabolisme, dan produksi hormon pemicu kecemasan atau stres mengalami penurunan. ${ }^{16}$

Kecemasan ibu hamil berisiko tinggi mengalami komplikasi obstetri, termasuk persalinan yang sulit, preeklampsia, dan kelahiran prematur. Gejala fisik seperti mual dan muntah, nyeri ulu hati, dan nyeri otot selama kehamilan juga lebih sering terjadi pada wanita dengan kecemasan perinatal. Kecemasan akan mempengaruhi perkembangan anak seperti apgar score yang rendah, serta perkembangan emosional anak. ${ }^{17,18}$ Pengendalian kecemasan ibu hamil dianggap penting untuk ditangani salah satunya dengan prenatal yoga. Maka perlu dilakukan penelitian mengenai perbedaan tingkat kecemasan pada ibu hamil trimester ketiga yang mengikuti prenatal yoga dengan ibu hamil trimester ketiga yang tidak mengikuti prenatal yoga.

\section{METODE}

Penelitian ini menggunakan desain penelitian observasi analitik komperatif dengan metode pendekatan cross sectional yang telah dilakukan pada bulan November-Desember 2019, di Klinik Bumi Sehat Gianyar. Penelitian ini telah disetujui oleh Komisi Etik Penelitian Fakultas Kedokteran Universitas Udayana tertanggal 30 Oktober 2019. Teknik yang digunakan untuk penentuan sampel adalah purposive sempling. Total sampel dalam penelitian ini adalah 80 ibu hamil. Sampel didapat melalui kriteria inklusi yaitu lbu hamil trimester ketiga yang berusia 20-35 tahun, pendidikan terakhir ibu hamil SD, SMP,SMA, atau PT, Ibu hamil primigravida maupun multigravida, ibu hamil yang mengikuti prenatal yoga minimal 6 kali, ibu hamil yang tidak mengikuti terapi musik, aromaterapi, teknik relaksasi, dan hypnobrithing. Kriteria eksklusinya yaitu ibu hamil dengan riwayat obstetrik buruk seperti perdarahan dalam kehamilan, menderita kelainan jantung, anemia berat, asthma atau masalah paru-paru kronik, serviks inkompeten, ataupun kelainan letak plasenta.

Variabel independen dalam penelitian ini adalah prenatal yoga. Variabel dependen adalah tingkat kecemasan, sedangkan variabel kontrol dalam penelitian ini yaitu ibu hamil trimester ketiga, Ibu hamil usia 20-35 tahun, paritas, pendidikan terakhir, ekonomi, dukungan suami dan keluarga. Pengumpulan data diawali dengan menjelaskan maksud dan tujuan penelitian, selanjutnya diminta mengisi informed consent sebagai bentuk persetujuan menjadi responden penelitian. Instrument yang digunakan dalam penelitian ini adalah kuesioner yang berisi identitas umum dan hal terkait lainnya dan kuesioner Depression Anxiety Stress Scale 42 (DASS 42) untuk mengukur tingkat kecemasan ibu hamil. Kemudian semua data variabel penelitian akan dianalisis dengan uji statistik menggunakan komputer dengan perangkat lunak SPSS versi 16.0. Hasil data yang diperoleh akan diuji analisis menggunakan uji statistik deskripstif, uji analisis bivariat dengan uji Chi-Square tets untuk melihat adanya Perbedaan Tingkat Kecemasan Ibu Hamil Trimester Ketiga 
yang Menikuti Prenatal Yoga dengan Ibu Hamil Trimester Ketiga yang Tidak Mengikuti Prenatal Yoga di Kabupaten Gianyar.

\section{HASIL}

Karakteristik sampel yang diamati dalam penelitian ini adalah usia, paritas, pendidikan, dukungan suami dan keluarga. Sampel dalam penelitian ini merupakan ibu hamil trimester ketiga di Klinik Bumi Sehat Gianyar. Pengambilan sampel menggunakan teknik purposive sampling dengan jumlah sampel dalam penelitian ini adalah sejumlah 80 ibu hamil yang dibagi menjadi dua kelompok yaitu kelompok ibu hamil yang mengikuti prenatal yoga dan kelompok ibu hamil yang tidak mengikuti prenatal yoga. Masing-masing kelompok terdiri dari 40 ibu hamil.

Tabel 1. Distribusi Frekuensi Karakteristik Sampel

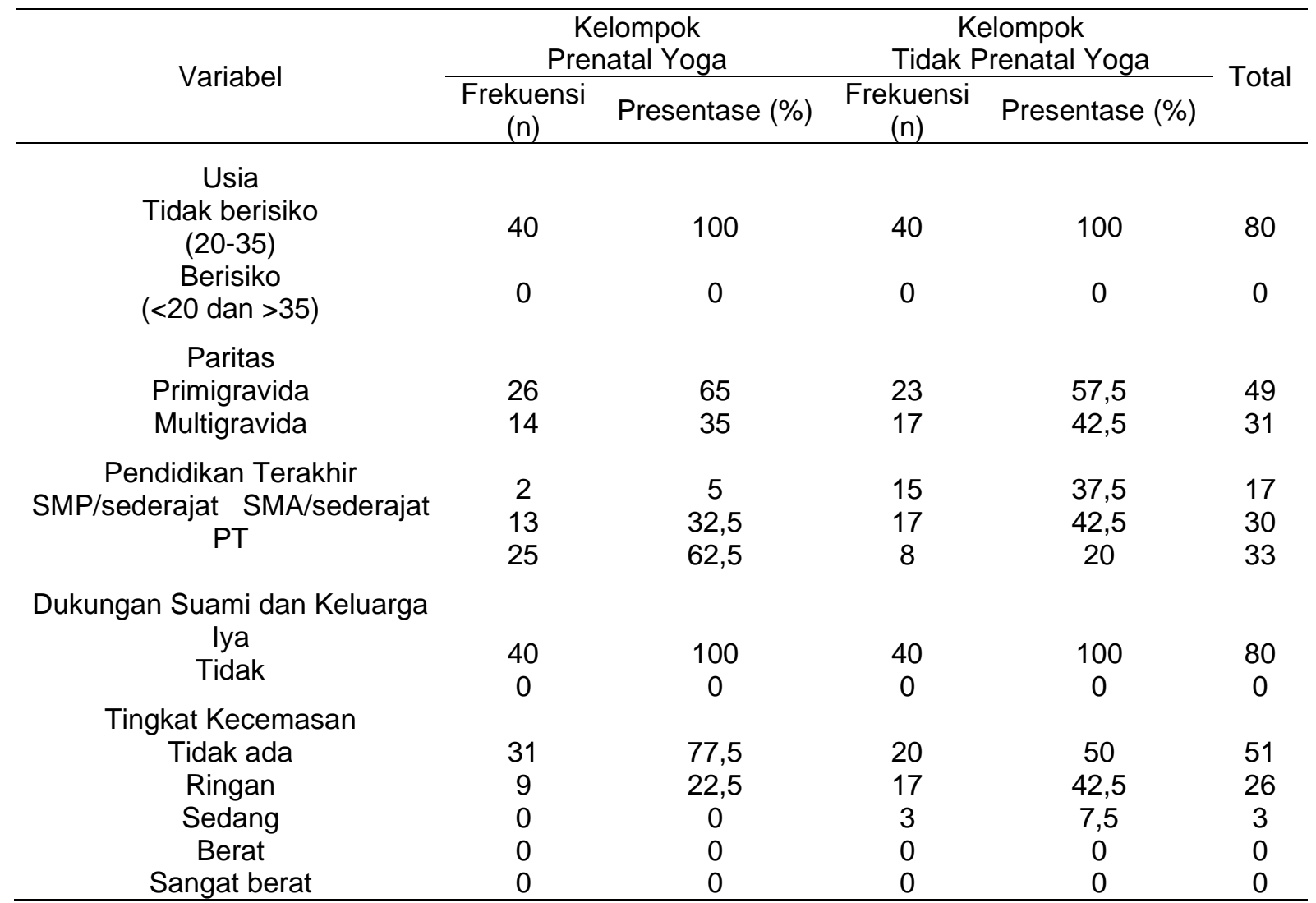

Berdasarkan Tabel 1. maka diketahui bahwa usia responeden berkisar 20-35 tahun yang dimana usia tersebut merupakan usia yang dianggap paling aman menjalani kehamilan dan persalinan. Mayoritas paritas responden pada kelompok prenatal yoga terdapat primigravida sejumlah 26 ibu hamil (65\%), mayoritas pada kelompok tidak prenatal yoga terdapat primigravida sejumlah 23 ibu hamil (57,5\%). Pendidikan terakhir responden terbanyak pada kelompok prenatal yoga adalah PT (Perguruan Tinggi) sebanyak 25 ibu hamil (62,5\%) dan terendah SMP/sederajat sebanyak 2 ibu hamil (5\%), pada kelompok tidak prenatal yoga responden terbanyak SMA/sederajat 17 ibu hamil (42,5\%) dan terendah PT (Perguruan Tinggi) sebanyak 8 ibu hamil (20\%). Seluruh responden yaitu 80 ibu hamil yang dibagi menjadi dua kelompok prenatal yoga dan tidak prenatal yoga mendapatkan dukungan suami dan keluarga (100\%). Dilihat dari sebaran kuesioner untuk melihat tingkat kecemasan responden pada kelompok prenatal yoga mayoritas ibu hami tidak mengalami kecemasan yaitu 31 ibu hamil (77,5\%) diikuti 9 ibu hamil mengalami kecemasan ringan (22,5\%), pada kelompok ibu hamil yang tidak mengikuti prenatal yoga terdapat 20 ibu hami tidak mengalami kecemasan (50\%), $17 \mathrm{ibu}$ hami mengalami kecemasan ringan (42,5\%) 3 ibu hamil mengalami kecemasan sedang (7,5\%), dan tidak ada yang mengalami kecemasan berat maupun sangat berat $(0 \%)$.

Tabel 2. Hasil Analisis Data Chi Square Perbedaan Tingkat Kecemasan Ibu Hamil Trimester Ketiga yang Mengikuti Prenatal Yoga dengan Ibu Hamil Trimester Ketiga yang Tidak Mengikuti Prenatal Yoga

\begin{tabular}{|c|c|c|c|c|c|}
\hline \multirow{2}{*}{ Keikutsertaan Prenatal Yoga } & \multicolumn{3}{|c|}{ Tingkat Kecemasan } & \multirow{2}{*}{ Total } & \multirow{2}{*}{$\mathrm{P}$} \\
\hline & Tidak Ada & Ringan & Sedang & & \\
\hline Prenatal Yoga & $\begin{array}{c}31 \\
(77,5 \%)\end{array}$ & $\begin{array}{c}9 \\
(22,5 \%)\end{array}$ & $\begin{array}{c}0 \\
(0 \%)\end{array}$ & 40 & \\
\hline Tidak Prenatal Yoga & $\begin{array}{c}20 \\
(50 \%)\end{array}$ & $\begin{array}{c}17 \\
(42,5 \%)\end{array}$ & $\begin{array}{c}3 \\
(7,5 \%)\end{array}$ & 40 & 0,020 \\
\hline Total & $\begin{array}{c}51 \\
(63,8 \%)\end{array}$ & $\begin{array}{c}26 \\
(32,5 \%)\end{array}$ & $\begin{array}{c}3 \\
(3,8 \%)\end{array}$ & 80 & \\
\hline
\end{tabular}

Berdasarkan hasil yang diperoleh pada Tabel 2. mengenai perbedaan tingkat kecemasan pada ibu hamil yang mengikuti prenatal yoga dengan yang tidak mengikuti prenatal yoga diketahui bahwa nilai $p$ sebesar 0,020 sehingga nilai $p<0,05$. Dengan demikian dapat dinyatakan bahwa hipotesis Ho ditolak dan Ha diterima, sehingga ditemukan 
adanya perbedaan tingkat kecemasan antara ibu hamil trimester ketiga yang mengikuti prenatal yoga dengan ibu hamil trimester ketiga yang tidak mengikuti prenatal yoga di Kabupaten Gianyar.

\section{DISKUSI \\ Karakteristik Responden}

Penelitian ini dilakukan di Klinik Bumi Sehat Gianyar pada bulan November dan Desember 2019. Responden dalam penelitian ini sebanyak 80 ibu hamil trimester ketiga yang berusia 20-35 tahun serta yang memenuhi kriteria inklusi dan ekslusi. Pengambilan sampel dalam penelitian ini menggunakan teknik purposive sampling.

Hasil penelitian menunjukan dari 80 ibu hamil yang dibagi menjadi dua kelompok yaitu kelompok prenatal yoga yang sebanyak 40 orang dan kelompok tidak prenatal yoga sebanyak 40 orang diketahui bahwa paritas responden pada kelompok prenatal yoga terdapat primigravida sejumlah 26 ibu hamil (65\%) dan mutigravida sebanyak 14 ibu hamil (35\%) sedangkan pada kelompok tidak prenatal yoga terdapat primigravida sejumlah 23 ibu hamil (57,5 \%) dan mutigravida sebanyak 17 ibu hamil (42,5\%). Kecemasan pada primigravida dapat disebabkan karena ketidaktahuan ditambah cerita pengalaman kehamilan yang kurang baik dari wanita lain. Ibu yang pernah melahirkan sebelumnya (multigravida), kecemasan berhubungan dengan pengalaman melahirkan sebelumnya. ${ }^{1}$ Pengalaman seperti lama persalinan yang diakibatkan oleh kondisi fisik atau pinggul yang sempit, pernah mengalami sectio caesaria, pengalaman abortus juga dapat menimbulkan guncangan hebat dan rasa tidak percaya pada ibu multigravida. ${ }^{19}$

Perbedaan tingkat kecemasan juga bisa dipengaruhi oleh faktor pendidikan, mengingat latar belakang pendidikan secara tidak langsung akan berpengaruh terhadap pola pikir dan prilaku seseorang tentang sesuatu hal terutama yang berkaitan dengan derajat kesehatan. Seseorang akan lebih mudah menerima informasi baru yang disampaikan baik secara langsung maupun tidak langsung dibandingkan dengan seseorang yang mempunyai latar belakang pendidikan yang rendah. ${ }^{9}$ Pendidikan terakhir responden pada penelitian ini tidak dapat dikontrol karena ibu hamil yang berpendidikan tinggi lebih banyak memilih mengikuti prenatal yoga. Distribusi pendidikan terakhir responden pada kelompok prenatal yoga setingkat SMP/sederajat sebanyak 2 ibu hamil (5\%), SMA/sederajat 13 ibu hamil (32,5\%), dan PT (Perguruan Tinggi) sebanyak 25 ibu hamil (62,5\%), sedangkan pada kelompok tidak prenatal yoga terdapat SMP/sederajat sebanyak 15 ibu hamil (37,5\%), SMA/sederajat 17 ibu hamil (42,5\%), dan PT (Perguruan Tinggi) sebanyak 8 ibu hamil (20\%).

Dukungan suami merupakan bentuk nyata dari kepedulian dan tanggung jawab suami dalam kehamilan dan kehidupan istri. Tanggung jawab tersebut bisa berupa mengawasi, memelihara dan melindungi istri serta menjaga bayi yang dikandung. ${ }^{20,21}$ Dukungan keluarga merupakan bantuan yang diberikan dari anggota keluarga lain berupa barang, jasa, informasi dan nasehat, yang mana membuat penerima dukungan akan merasa disayang, dihargai dan tentram. Dukungan suami dan keluarga yang baik akan mengurangi stressor pada ibu hamil selama kehamilan dan persalinan, sehingga proses persalinan lebih lancar dan cepat tanpa menimbulkan komplikasi. ${ }^{5}$ Seluruh responden pada penelitian ini yaitu sebanyak 80 ibu hamil yang dibagi menjadi dua kelompok prenatal yoga dan tidak prenatal yoga mendapatkan dukungan suami dan keluarga (100\%).

Dilihat dari sebaran kuesioner Depression Anxiety Stress Scale 42 (DASS 42) untuk melihat tingkat kecemasan responden pada kelompok prenatal yoga terdapat 31 ibu hami tidak mengalami kecemasan $(77,5 \%)$ dan 9 ibu hamil mengalami kecemasan ringan $(22,5 \%)$, pada kelompok ibu hamil yang tidak mengikuti prenatal yoga terdapat 20 ibu hami tidak mengalami kecemasan (50\%), 17 ibu hami mengalami kecemasan ringan (42,5\%) 3 ibu hamil mengalami kecemasan sedang $(7,5 \%)$, dan tidak ada yang mengalami kecemasan berat maupun sangat berat (0\%). Kecemasan dibagi menjadi 4 yaitu kecemasan ringan, kecemasan sedang, kecemasan berat dan kecemasan sangat berat atau panik. Menurut Riyandi \& Purwanto tahun 2009, kecemasan ringan berhubungan dengan ketegangan dalam kehidupan sehari-hari sehingga menyebabkan seseorang menjadi waspada dan meningkatkan lahan persepsinya. Kecemasan ringan dengan nilai 8-9, diukur dengan Depression Anxiety Stress Scale 42 (DASS 42). Kecemasan sedang dengan nilai 10-14 merupakan keadaan yang memungkinkan seseorang untuk memusatkan pada hal yang penting dan mengesampingkan hal yang lain, sehingga seseorang menjadi tidak perhatian yang selektif namun dapat melakukan sesuatu yang lebih banyak jika diberi arahan. Kecemasan berat merupakan keadaan yang dimana sangat mengurangi lahan persepsi seseorang. Individu cenderung untuk berfokus pada sesuatu yang terinci dan spesifik serta tidak dapat memikirkan hal lain. Semula perilaku ditujukan untuk mengurangi ketegangan. Individu yang mengalami kecemasan ini memerlukan banyak pengarahan untuk dapat berfokus pada hal lain. Nilai kecemasan berat dalam Depression Anxiety Stress Scale 42 (DASS 42) yaitu 15-19. Kecemasan sangat berat atau panik berhubungan dengan terperangah, ketakutan dan terror. Individu mengalami hilang kendali sehingga tidak mampu melakukan sesuatu walaupun dengan arahan. Panik melibatkan disorganisasi kepribadian dan peningkatan aktivitas motorik, sulit berhubungan dengan orang lain, persepsi yang menyimpang dan kehilangan pemikiran yang rasional Nilai kecemasan sangat berat dalam Depression Anxiety Stress Scale 42 (DASS 42) yaitu $\geq 20.4$

\section{Perbedaan Tingkat Kecemasan pada Ibu Hamil Trimester Ketiga Yang Mengikuti Prenatal Yoga Dengan Yang Tidak Mengikuti Prenatal Yoga}

Prenatal yoga selain memberi manfaat secara fisik pada ibu hamil seperti meningkatkan kekuatan dan stamina tubuh ibu hamil, melancarkan sirkulasi darah dan asupan oksigen ke janin, mengatasi sakit punggung dan pinggang, skiatika, sembelit, pegal-pegal, menguatkan otot perineum (otot dasar panggul) dan mengajarkan teknik-teknik penguasaan tubuh yang bermanfaat untuk mempermudah proses melahirkan serta mempercepat proses pemulihan pasca melahirkan. Prenatal yoga juga melatih berkomunikasi dengan anak sejak masih di dalam kandungan, yoga juga dapat mengurangi kecemasan dan persiapan mental ibu menghadapi persalinan. ${ }^{22}$ Pratignyo tahun 2014 menyebutkan bahwa prenatal yoga berfungsi meningkatkan kesadaran dan kepercayaan diri pada ibu hamil dan menciptakan ikatan 
batin antara ibu dan bayi yang dikandung. ${ }^{14}$ Melakukan yoga secara rutin juga dapat membantu mencegah penurunan fungsi kognitif. ${ }^{23}$

Penelitian yang dilakukan oleh Alza dkk tahun 2017 menyimpulkan bahwa latihan prenatal yoga dapat mengurangi kecemasan ibu hamil trimester ketiga antara pretest dan posttest pada kelompok prenatal yoga dibanding kelompok yang tidak melakukan yoga. ${ }^{16}$ Satyapriya dkk pada tahun 2013 menyimpulkan bahwa latihan prenatal yoga dapat mengurangi kecemasan, depresi dan pengalaman tidak nyaman terkait kehamilan. Penelitian tersebut membandingkan latihan yoga dengan latihan antenatal standar. ${ }^{24}$ Hasil penelitian ini didukung pula oleh penelitian lain yang dilakukan Wulandari dkk pada tahun 2018 di Semarang Selatan yang menyimpulkan bahwa yoga berpengaruh positif dan signifikan terhadap penurunan tingkat kecemasan primigravida trimester II dan III. ${ }^{25} \mathrm{Hal}$ ini dapat terjadi karena penerapan prenatal yoga pada ibu hamil secara rutin dapat menjaga kesehatan tubuh ibu hamil baik secara fisik maupun psikisnya.

Hasil dalam penelitian ini menunjukkan bahwa ibu hamil trimester ketiga yang telah mengikuti prenatal yoga lebih dari 6 kali latihan memiliki kesehatan secara mental yang lebih baik dibandingkan dengan ibu hamil yang tidak mengikuti prenatal yoga. Yoga dirancang untuk membawa keseimbangan dan kesehatan fisik, mental, emosional, dan spiritual dari individu. ${ }^{26}$ lbu hamil yang mengalami kecemasan atau stress dapat mengaktifkan hipotalamus yang kemudian mengendalikan dua sistem neuroendokrin yaitu sistem saraf simpatis dan korteks adrenal, yang kemudian menstimulasi pelepasan beberapa hormon termasuk kortisol yang merupakan salah satu hormon pemicu stres. ${ }^{27}$ Ketika seseorang stres, hipotalamus akan menghantarkan impuls saraf ke nukleus-nukleus di batang otak yang mengendalikan fungsi sistem saraf otonom dan mengaktifkan saraf simpatis yang beraksi langsung pada otot polos dan organ internal dan juga menstimulasi medula adrenal untuk melepaskan hormon epinefrin (adrenalin) dan norepinefrin ke dalam pembuluh darah, sehingga berdampak meningkatkan denyut jantung dan tekanan darah, dan norepinefrin secara tidak langsung melalui aksinya pada kelenjar hipofisis melepaskan gula dari hati. Hormon adrenokortikotropik (ACTH) menstimulasi lapisan luar kelenjar adrenal (korteks adrenal) yang menyebabkan pelepasan hormon (salah satu yang utama adalah kortisol) yang meregulasi kadar glukosa dan mineral tertentu. ${ }^{28}$

Prenatal yoga merupakan modifikasi dari yoga pada umumnya yang telah disesuaikan dengan kondisi fisik ibu hamil, dengan tujuan menghindari cedera dan memberikan rasa nyaman dan aman bagi ibu hamil..21 Gerakan prenatal yoga yang lambat dan dibarengi latihan pernapasan akan dapat mengurangi kinerja hipotalamus untuk melepaskan neuropeptida yang selanjutnya akan merangsang kelenjar hipofisis untuk melepaskan ACTH, yang kemudian menekan produksi kortisol.29 Mengatur pernapasan pada saat gerakan yoga akan menstimulus hipotalamus, kemudian hipotalamus akan menghantarkan impuls saraf ke nukleus-nukleus di batang otak yang mengendalikan fungsi sistem saraf otonom dan mengaktifkan sistem saraf parasimpatis terutama dengan meregangkan jaringan paru-paru sehingga memberikan suplay oksigen yang baik kemudian memberikan respons fisiologis yang ditandai dengan penurunan denyut jantung, irama nafas, ketegangan otot, tekanan darah, tingkat metabolisme, dan produksi hormon pemicu kecemasan atau stres mengalami penurunan. ${ }^{16,30}$ Yoga juga menurunkan kadar kortisol saliva, glukosa darah, serta kadar rennin plasma, dan norepinephrine dan epinefrin 24 jam. Yoga secara signifikan menurunkan denyut jantung dan tekanan darah sistolik dan diastolik. Penelitian menunjukkan bahwa yoga membalikkan dampak negatif stres pada sistem kekebalan tubuh dengan meningkatkan kadar imunoglobulin A12. ${ }^{26}$

\section{SIMPULAN}

Berdasarkan hasil penelitian yang telah dilakukan dan pembahasan yang telah dipaparkan, maka simpulan dari penelitian ini adalah "Terdapat perbedaan tingkat kecemasan ibu hamil trimester ketiga yang mengikuti prenatal yoga dengan ibu hamil trimester ketiga yang tidak mengikuti prenatal yoga di Kabupaten Gianyar dengan nilai $p<0.05 . "$

\section{SARAN}

Saran yang dapat diberikan oleh peneliti adalah sebagai berikut:

1. Penelitian ini dapat memberikan edukasi terkait perubahan yang dialami selama kehamilan terutama perubahan psikologis ibu hamil dan hubungannya dengan keikutsertaan prenatal yoga. lbu hamil disarankan untuk mengikuti prenatal yoga.

2. Penelitian ini dapat menjadi data ilmiah sehingga dapat menunjang penelitian selanjutnya. Bagi peneliti yang ingin melanjutkan penelitian ini diharapkan dapat melakukan penelitian eksperimen dengan memberikan latihan prenatal yoga agar dapat mengetahui seberapa signifikan prenatal yoga dapat menurunkan tingkat kecemasan ibu hamil.

\section{DAFTAR PUSTAKA}

1. Zamriati,W.O., Hutagaol, E, Wowiling, F.,2013. Faktor-faktor yang berhubungan dengan kecemasan ibu hamil menjelang persalinan di Poli KIA PKM Tuminting. Jurnal Keperawatan, 1(1).

2. Marniati, M.N.T., 2017, January. Analisis Tingkat Kecemasan lbu Kehamilan Pertama Dalam Menghadapi Persalinan. In Prosiding Seminar Nasional Ikakesmada "Peran Tenaga Kesehatan dalam Pelaksanaan SDGs". Fakultas Kesehatan Masyarakat Universitas Ahmad Dahlan, 107-112.

3. Litsmanasari, A., 2013. Perbedaan Tingkat Kecemasan Menghadapi Persalinan pada Ibu Primigravida dan Multigravida Trimester III di Puskesmas Sanden Bantul (Doctoral dissertation, STIKES'Aisyiyah Yogyakarta).

4. Riyandi,S. dan Purwanto, T., 2009, Asuhan Keperawatan Jiwa, Yogyakarta, Graha IImu.

5. Arifin, A., Kundre, R. and Rompas, S., 2015. Hubungan Dukungan Keluarga Dengan Kecemasan Ibu Hamil Menghadapi Proses Persalinan Di Puskesmas Budilatama Kecamatan Gadung Kabupaten Buol Propinsi Sulawesi Tengah. Jurnal Keperawatan, 3(2).

6. Said, N., Kanine, E. and Bidjuni, H., 2015. Hubungan Faktor Sosial Ekonomi Dengan Kecemasan Ibu Primigravida Di Puskesmas Tuminting. Jurnal Keperawatan, 3(2). 
7. Diani, L.P.P. and Susilawati, L.K.P.A., 2013. Pengaruh dukungan suami terhadap istri yang mengalami kecemasan pada kehamilan trimester ketiga di Kabupaten Gianyar. Jurnal Psikologi Udayana, 1(1).

8. Dennis, C., Falah-Hassani, K.,Shiri, R., 2017. Prevalence of antenatal and postnatal anxiety: Systematic review and meta-analysis. British Journal of Psychiatry, 210(05), pp.315-323.

9. Rosyidah, N.N.,2015. Gambaran Tingkat Kecemasan Ibu Primigravida Trimester III Dalam Menghadapi Persalinan Di Bps Ny. Roidah, Sst,M.Kes Desa Dlanggu Mojokerto. Jurnal Keperawatan dan Kebidanan.

10. Chen, P., Yang, L., Chou, C., Li, C., Chang, Y. and Liaw, J. (2017). Effects of prenatal yoga on women's stress and immune function across pregnancy: A randomized controlled trial. Complementary Therapies in Medicine, 31, pp.109-117.

11. Martalisa, W. and Budisetyani, W., 2013. Hubungan Intensitas Keikutsertaan Hypnobirthing dengan Tingkat Kecemasan Ibu Hamil di Gianyar. Jurnal Psikologi Udayana, 1(1), pp.116-128.

12. Field, T., 2011. Yoga clinical research review. Complementary Therapies in Clinical Practice, 17(1), pp.1-8.

13. Negari, K.W. and Christiani, N., 2017. Manfaat Prenatal Yoga Terhadap Proses Persalinan. In Seminar Nasional Kebidanan. 1(1). pp. 305-310.

14. Pratignyo, T., 2014. Yoga Ibu Hamil. Puspa Swara.

15. Guyton dan Hall, 2016. Buku Ajar Fisiologi Kedokteran, Jakarta, Elsevier: 725- 737.

16. Alza, N., Nurdiati, D.S., Ismarwati, 2017. Pengaruh Yoga Terhadap Kecemasan lbu Hamil Trimester III di Puskesmas Wilayah Kota Yogyakarta. Jurnal Universitas 'Aisyiyah Yogyakarta.

17. Furtado, M., Chow, C., Owais, S., Frey, B. and Van Lieshout, R. (2018). Risk factors of new onset anxiety and anxiety exacerbation in the perinatal period: A systematic review and meta-analysis. Journal of Affective Disorders, 238, pp.626-635.

18. Annatalgia, L., dan Retnowati, S., 2011. Pelatihan Relaksasi Bumil Sehat Untuk Menurunkan Kecemasan Ibu Hamil Risiko Tinggi. Jurnal Intervensi Psikologi, 3(1).

19. Sih Utami, P.R.A.D.I.P.T.A., 2012. Perbedaan Tingkat Kecemasan Antara Pasien Primigravida dan Multigravida Pada Kehamilan Trimester Ketiga Di Rumah Sakit Umum Daerah Kota Surakarta (Doctoral dissertation, Universitas Muhammadiyah Surakarta).

20. Lowdermilk, D. L., Perry, S. E., \& Cashion, K. (2013). Keperawatan Maternitas (Felicia Sidharta \& Anesia Tania, Penerjemah). Jakarta: Salemba Medika.

21. Widiantari, N. K. N. (2015). Hubungan Karakteristik Ibu dan Dukungan Sosial Suami dengan Partisipasi Ibu Mengikuti Kelas Ibu Hamil di Kota Denpasar. Skripsi Universitas Udayana.

22. Sindhu, P., 2009. Yoga Untuk Kehamilan: Sehat, Bahagia\& Penuh Makna. Qanita.

23. Wahyuni, N., Nugraha, M. H. S., \& Juhanna, I. V. 2018. Olahraga Dapat Meningkatkan Fungsi Kognitif Melalui Modulasi Epigenetik Ekspresi Gen Brain-Derived Neurotrophic Factor (Bdnf). Sport and Fitness Journal, 6(3),2430.

24. Satyapriya, M., Nagarathna, R., Padmalatha, V. and Nagendra, H.R., 2013. Effect of integrated yoga on anxiety, depression \& well being in normal pregnancy. Complementary therapies in clinical practice, 19(4), pp.230-236.

25. Wulandari, P., Retnaningsih, D., Aliyah, E.,2018. Pengaruh Prenatal Yoga Terhadap Tingkat Kecemasan Pada Ibu Primigravida Trimester II Dan III Di Studio Qita Yoga Kecamatan Semarang Selatan Indonesia. Jurnal Keperawatan, $9(1)$.

26. Ross, A., and Thomas, S.,(2010). The Health Benefits of Yoga and Exercise: A Review of Comparison Studies. The Journal Of Alternative And Complementary Medicine, 16(1), pp. 3-12.

27. Sari, N.P.A.R. and Utami, P.A.S., 2015. Pengaruh Senam Otak Terhadap Tingkat Stres Lansia di Panti Sosial Tresna Werdha Jara Mara Pati Singaraja. Jurnal Keperawatan Sriwijaya, 2(1), pp.30-35.

28. Primadita, A., 2012. Efektifitas Intervensi Terapi Musik Klasik Terhadap Stress Dalam Menyusun Skripsi Pada Mhasiswa PSIK Undip Semarang (Doctoral dissertation, Diponegoro University).

29. Hamdiah, H., Suwondo, A., Hardjanti, T. S., Soejoenoes, A., \& Anwar, M. C. (2017). Effect of prenatal yoga on anxiety, blood pressure, and fetal heart rate in primigravida mothers. Belitung Nursing Journal, 3(3), 246-254. 30. Babbar, S. and Shyken, J., 2016. Yoga in pregnancy. Clinical obstetrics and gynecology, 59(3), pp.600-612. 